\title{
Thermodynamics of Neptunium (V) Complexes with Phosphate at Elevated Temperatures
}

\author{
Yuanxian Xia $^{1 *}$, Judah I. Friese ${ }^{1}$, Paula P. Bachelor ${ }^{1}$, Dean A. Moore ${ }^{1}$, Linfeng. Rao ${ }^{2}$ \\ 1. Pacific Northwest National Laboratory, P. O. Box 999, Richland, WA 99352 \\ 2. Lawrence Berkeley National Laboratory, Berkeley, CA 94720
}

\begin{abstract}
The complexation of $\mathrm{Np}(\mathrm{V})$ with phosphate at elevated temperatures has been studied by a synergistic extraction method. A mixed buffer solution of TRIS and MES was used to maintain an appropriate $\mathrm{pH}$ value during the distribute experiments. The distribution ratio of $\mathrm{Np}(\mathrm{V})$ between the organic and aqueous phases was found to decrease as the concentrations of phosphate were increased. Stability constants of the 1:1 and 1:2 $\mathrm{Np}(\mathrm{V})-\mathrm{HPO}_{4}{ }^{2-}$ complexes, dominant in the aqueous phase under the experimental conditions, were calculated from the effect of $\left[\mathrm{HPO}_{4}{ }^{2-}\right]$ on the distribution ratio. The thermodynamic parameters including enthalpy and entropy of complexation between $\mathrm{Np}(\mathrm{V})$ and $\mathrm{HPO}_{4}{ }^{2-}$ at $25^{\circ} \mathrm{C}-55^{\circ} \mathrm{C}$ were calculated by the temperature coefficient method.
\end{abstract}

\section{INTRODUCTION}

Neptunium is one of the radionuclides of concern in the post-closure chemical environment in the proposed Yucca Mountain repository due to its high toxicity and very long half life $\left({ }^{237} \mathrm{~Np}, \mathrm{t}_{1 / 2}=2.14 \times 10^{6}\right.$ years $)$ as well as its high abundance in the nuclear waste. The fractional dose attributed to ${ }^{237} \mathrm{~Np}$ will reach $67 \%$ at 75,000 years ${ }^{1}$. As a result, the migration of neptunium in the post-closure chemical environment of waste repositories and the surrounding geologic media is of great concern to longterm repository performance. $\mathrm{Np}(\mathrm{V})$ is the most stable oxidation state under environmental and nuclear waste conditions where $\mathrm{O}_{2}$ overpressure is approximate $20 \%{ }^{1}$. The solubility of neptunium after disposal will depend largely on its reactions (e.g., dissolution/precipitation and complexation) with various components present in the repository. The interactions of actinides with some inorganic ligands at elevated temperatures may be a significant factor in determining the solubility and migration of the actinides in the nuclear waste repository. For example, phosphate is expected to be present in the water in contact with the nuclear waste packages and affect the speciation and migration of actinides by forming complexes ${ }^{1-2}$. Studies of complexation of $\mathrm{Np}(\mathrm{V})$ with various inorganic ligands have recently reviewed ${ }^{3}$. There have been several studies of the aqueous $\mathrm{Np}(\mathrm{V})$ phosphate system using spectrophotometric ${ }^{4}$, ion exchange $^{5-6}$, solvent extraction ${ }^{7}$ or co-precipitation methods ${ }^{8}$. But all these data on the stability constants of $\mathrm{Np}(\mathrm{V})$ complexes with phosphate were obtained at the *E-mail: yuanxian.xia@pnl.gov room temperature. Only Rees and Danie ${ }^{6}$ reported their data on the stability constants of $\mathrm{Np}(\mathrm{V})$ complexes with $\mathrm{HPO}_{4}{ }^{2-}$ at different temperatures $\left(10,25\right.$ and $\left.35^{\circ} \mathrm{C}\right)$. In fact, no data are available in the $\mathrm{Np}(\mathrm{V})-\mathrm{HPO}_{4}{ }^{2-}$ system at temperatures $>35^{\circ} \mathrm{C}$ in the literature. It is well known that the equilibrium constants of complexation could vary by orders of magnitude in the temperature range $\left(25-80^{\circ} \mathrm{C}\right)$ relevant to waste repositories. In order to minimize the uncertainty in the prediction of $\mathrm{Np}(\mathrm{V})$ migration, it is necessary to know sufficient and reliable thermodynamic data on its complexes at elevated temperatures. Unfortunately, experimental data on the effects of temperatures in these systems are very scarce at present.

In this work, a solvent extraction method ${ }^{9-11}$ was used to determine the stability constants of $\mathrm{Np}(\mathrm{V})$ complexes with phosphate anions at $I=1.0 \mathrm{M} \mathrm{NaClO}_{4}$ and $t=25^{\circ}$ $55^{\circ} \mathrm{C}$. It is expected that $\mathrm{HPO}_{4}{ }^{2-}$ anion is the dominant species in the aqueous phase at $\mathrm{pcH}\left(=-\log \left[\mathrm{H}^{+}\right]\right)$about 7.4. A synergist of trioctyl phosphine oxide (TOPO) and 2-thenoyltrifluoroacetone (TTA) was used as a solvent extractant and toluene as a solvent.

In the system of $\mathrm{Np}(\mathrm{V})$-phosphate complexes, there is possibility of the formation of different species of complexes. The complex reactions of $\mathrm{Np}(\mathrm{V})$ with $\mathrm{H}_{2} \mathrm{PO}_{4}{ }^{-}$ and $\mathrm{HPO}_{4}{ }^{2-}$ anions under experimental conditions used in this study can be expressed as (species $\mathrm{PO}_{4}{ }^{3-}$ can be neglected):

$$
\begin{aligned}
& \mathrm{NpO}_{2}{ }^{+}+\mathrm{pH}_{2} \mathrm{PO}_{4}{ }^{-}=\mathrm{NpO}_{2}\left(\mathrm{H}_{2} \mathrm{PO}_{4}\right)_{\mathrm{p}}{ }^{1-\mathrm{p}} \\
& \mathrm{NpO}_{2}{ }^{+}+\mathrm{q} \mathrm{HPO}_{4}{ }^{2-}=\mathrm{NpO}_{2}\left(\mathrm{HPO}_{4}\right)_{\mathrm{q}}{ }^{1-2 \mathrm{q}}
\end{aligned}
$$


with the overall stability constants $\beta_{\mathrm{p}}$ and $\beta_{\mathrm{q}}$ defined as:

$$
\begin{aligned}
& \beta_{\mathrm{p}}=\left[\mathrm{NpO}_{2}\left(\mathrm{H}_{2} \mathrm{PO}_{4}\right)_{\mathrm{p}}{ }^{1-\mathrm{p}}\right] /\left(\left[\mathrm{NpO}_{2}{ }^{+}\right]\left[\mathrm{H}_{2} \mathrm{PO}_{4}^{-}\right]^{\mathrm{p}}\right) \\
& \beta_{\mathrm{q}}=\left[\mathrm{NpO}_{2}\left(\mathrm{HPO}_{4}\right)_{\mathrm{q}}{ }^{1-2 \mathrm{q}}\right] /\left(\left[\mathrm{NpO}_{2}{ }^{+}\right]\left[\mathrm{HPO}_{4}{ }^{2-}\right]^{\mathrm{q}}\right)
\end{aligned}
$$

In the solvent extraction system, the distribution ratio (D) of a metal ion, $\mathrm{M}$, is defined as:

$$
\mathrm{D}=\Sigma[\mathrm{M}]_{\mathrm{o}} / \Sigma[\mathrm{M}]_{\mathrm{a}}
$$

Where $\Sigma[\mathrm{M}]_{\mathrm{o}}$ is total concentration of metal ion in the organic phase assuming there is only a single organic (o) phase, $\Sigma[\mathrm{M}]_{\mathrm{a}}$ is total concentration of metal ion in the aqueous phase and there are various species in the aqueous phase (a). The equation (5) can be written, with the stability constants as expressed in the literature ${ }^{9-11}$ :

$$
\mathrm{D}_{\mathrm{o}} / \mathrm{D}=1+\Sigma \beta_{\mathrm{p}}\left[\mathrm{L}_{\mathrm{p}}\right]^{\mathrm{p}}+\Sigma \beta_{\mathrm{q}}\left[\mathrm{L}_{\mathrm{q}}\right]^{\mathrm{q}}
$$

Where $\mathrm{D}_{\mathrm{o}}$ is the distribution ratio in the absence of complexation in the aqueous phase. For the $\mathrm{Np}(\mathrm{V})$ phosphate complex system at a fixed $\mathrm{pcH}$ (about 7.4), M, $\mathrm{L}_{\mathrm{p}}, \mathrm{L}_{\mathrm{q}}$ stand for $\mathrm{Np}(\mathrm{V}), \mathrm{H}_{2} \mathrm{PO}_{4}^{-}, \mathrm{HPO}_{4}{ }^{2-}$, respectively. TOPO with TTA anion as a synergistic extractant, toluene as a solvent.

\section{EXPERIMENTAL}

\section{Reagents and solutions}

All solutions were prepared with distilled-deionized (DDI) water and all reagents used in this work were analytical grade or higher. The stock solutions of $1.0 \mathrm{M}$, $2.0 \mathrm{M} \mathrm{NaClO}_{4}$ (Aldrich) and $0.1 \mathrm{M} \mathrm{Na}_{2} \mathrm{HPO}_{4}$ (Aldrich) were prepared by dissolving appropriate amounts of these reagents in DDI water. Sodium perchlorate (Aldrich) was used for ionic strength adjustment without further purification. Perchloric acid (Aldrich) and $\mathrm{NaOH}(1.0 \mathrm{~N}$ standard, Aldrich) were used to adjust $\mathrm{pH}$. Buffer reagents of morpholinoethanesulfonic acid (MES,Alfa Aesar) and tri-hydroxy-methylaminomethane (TRIS, Alfa Aesar) were used to maintain $\mathrm{pcH}$ at about 7.4 in the aqueous solution. Sodium bromate (Aldrich) and $\mathrm{NaNO}_{2}$ (Aldrich) were used for oxidizing and reducing neptunium, respectively, during the preparation of stock solution of $\mathrm{NpO}_{2}{ }^{+}$. A mixture of $0.027 \mathrm{M}$ TTA (Aldrich) and 0.028 $\mathrm{M}$ TOPO (Aldrich) in toluene (Aldrich) was used as a synergistic extractant. TTA was purified by vacuum sublimation at $42^{\circ} \mathrm{C}$. TOPO was used without further purification. The organic solutions were pre-equilibrated with the aqueous stock solution of $1.0 \mathrm{M} \mathrm{NaClO}_{4}$ and stored in a dark glass bottle. All solutions except the $\mathrm{Np}(\mathrm{V})$ tracer solution were filtered with a $0.2 \mu \mathrm{m}$ microfiltration system to minimize sorption of $\mathrm{Np}(\mathrm{V})$ by suspended particles in solution.

A $\mathrm{Np}(\mathrm{V})$ stock solution was prepared using the procedure described in the literature ${ }^{12}$. A small amount of solid $\mathrm{NaBrO}_{3}$ was added to a solution of neptunium in 1.0 $\mathrm{M} \mathrm{HClO}_{4}$ and the solution warmed to facilitate the oxidation of neptunium to $\mathrm{Np}(\mathrm{VI})$. Then a small amount of $\mathrm{NaNO}_{2}$ was added to this solution causing a change in color from pink to green, indicating the reduction of $\mathrm{NpO}_{2}{ }^{2+}$ to $\mathrm{NpO}_{2}{ }^{+}$. Finally, the $\mathrm{NpO}_{2}{ }^{+}$species was precipitated by adding $1.0 \mathrm{M} \mathrm{NaOH}$ to the solution. The $\mathrm{NpO}_{2}(\mathrm{OH})$ precipitate was washed several times with DDI water and dissolved with $0.1 \mathrm{M} \mathrm{HClO}_{4}$. The oxidation state of $\mathrm{Np}(\mathrm{V})$ was confirmed spectrophotometrically on a Cary $500 \mathrm{UV}$-Vis-NIR Spectrophotometer. From the stock solution, a working solution of $\mathrm{Np}(\mathrm{V})$ was prepared in $0.06 \mathrm{~N} \mathrm{HClO}_{4}$. The activity of ${ }^{237} \mathrm{~Np}$ in the samples was measured on a Wallac (Model 1414) liquid scintillation counter (LSC). The $\beta$-activity of ${ }^{233} \mathrm{~Pa}$, the daughter nuclide of ${ }^{237} \mathrm{~Np}$, was automatically discriminated.

\section{Temperature-controlled extraction equipment}

The temperature-controlled extraction equipment used for this work has been described in a previous paper ${ }^{13}$. To shake the samples at the desired temperature, a reaction block with the heat tape or a block heater was used. Temperature control was accomplished through the block heater's temperature control or through a variable-voltage transformer when using the heat tape.

A Speedfuge (HSX10K) centrifuge with a water jacket enclosed around the rotor was used to centrifuge the samples. Water from a Brinkmann RM6 Lauda temperature controlled water circulator controlled the temperature of the samples inside the centrifuge.

Temperature adjusted reaction blocks are used to maintain the temperature of experimental solutions, samples, and $\mathrm{pH}$ buffers.

\section{Determination of $\mathrm{H}^{+}$concentrations}

A Corning $355 \mathrm{pH}$ meter was used with a combination glass electrode (Ross Orion) to measure the $\mathrm{pH}$. Because the $\mathrm{pH}$ was measured in the sodium perchlorate solution, the inner solution $(3 \mathrm{M} \mathrm{KCl})$ of the electrode was replaced with a saturated $\mathrm{NaCl}$ solution to avoid erratic electrode performance. The electrode was calibrated with $4.00,7.00$ and $10.00 \mathrm{pH}$ buffer standard solutions at the same elevated temperature as the reaction block. The $\mathrm{pH}$ meter readings $\left(\mathrm{pH}_{\mathrm{m}}\right)$ were converted to hydrogen concentration $\left(\mathrm{pcH}=-\log \left[\mathrm{H}^{+}\right]\right)$using the following 
calibration equation proposed by Irving et al. ${ }^{14}$ :

$$
\mathrm{pcH}=\mathrm{pH}_{\mathrm{m}}+\mathrm{b}
$$

Where $\mathrm{b}$ is the correction factor depending on the solution composition. For example, $\mathrm{b}=0.27$ in $1.0 \mathrm{M} \mathrm{NaClO}_{4}{ }^{9-10}$.

\section{Calculation of dissociation constants of phosphoric acid}

The free concentration of phosphate anion in each extraction vial was calculated from the measured $\mathrm{pH}$ (converting pcH), the total concentration of $\mathrm{Na}_{2} \mathrm{HPO}_{4}$ and the dissociation constants of phosphoric acid at the respective temperatures and ionic strength $1.0 \mathrm{M}$ $\mathrm{NaClO}_{4}$. Because $\mathrm{Np}(\mathrm{V})$ is at the tracer level and the amount of $\mathrm{Np}(\mathrm{V})-\mathrm{HPO}_{4}{ }^{2-}$ complex is negligible compared to the total amount of $\left[\mathrm{HPO}_{4}{ }^{2-}\right]_{\mathrm{T}}$. The concentration of free $\mathrm{HPO}_{4}{ }^{2-}$ anion $\left(\left[\mathrm{HPO}_{4}{ }^{2-}\right]_{\mathrm{f}}\right)$ can be calculated by using the equation (8):

$$
\left[\mathrm{HPO}_{4}{ }^{2-}\right]_{\mathrm{f}}=\left[\mathrm{HPO}_{4}{ }^{2-}\right]_{\mathrm{T}} /\left(1+\left[\mathrm{H}^{+}\right] / \mathrm{K}_{\mathrm{a} 2}+\left[\mathrm{H}^{+}\right]^{2} / \mathrm{K}_{\mathrm{a} 1} \mathrm{~K}_{\mathrm{a} 2}\right)
$$

Where $\mathrm{K}_{\mathrm{a} 1}$ and $\mathrm{K}_{\mathrm{a} 2}$ are the first and second dissociation constants of phosphoric acid, respectively. No data at high temperatures (such as $40^{\circ} \mathrm{C}$ and $55^{\circ} \mathrm{C}$ ) and ionic strength $\left(1.0 \mathrm{M} \mathrm{NaClO}_{4}\right)$ are available in the literature. The $\mathrm{K}_{\mathrm{a}}$ and $\mathrm{K}_{\mathrm{a} 2}$ were calculated based on the literature data at zero ionic strength and different temperatures ${ }^{15-16}$ by using Specific Ion Interaction Theory (SIT) ${ }^{17}$. In the SIT approach, such as the following protonation reaction:

$$
\mathrm{H}^{+}+\mathrm{L}_{\mathrm{q}}^{2-}=\mathrm{L}_{\mathrm{p}}^{-}
$$

Where as above mentioned $\mathrm{L}_{\mathrm{q}}{ }^{2-}$ and $\mathrm{L}_{\mathrm{p}}{ }^{-}$stand for $\mathrm{HPO}_{4}{ }^{2-}$ and $\mathrm{H}_{2} \mathrm{PO}_{4}{ }^{-}$, respectively. The equilibrium constant of above reaction at zero ionic strength $\mathrm{K}_{2}{ }^{\circ}$, is related to the constant $\mathrm{K}_{2}$ at ionic strength $\mathrm{I}_{\mathrm{m}}$ (in molality) by

$$
\log \mathrm{K}_{2}=\log \mathrm{K}_{2}{ }^{\mathrm{o}}+\Delta \mathrm{Z}^{2} \mathrm{D}-\Delta \varepsilon \mathrm{I}_{\mathrm{m}}
$$

Where $\Delta \mathrm{Z}^{2}=\mathrm{Z}_{\mathrm{p}}^{2}-\mathrm{Z}_{\mathrm{H}}{ }^{2}-\mathrm{Z}_{\mathrm{q}}{ }^{2}=-4, \mathrm{D}$ is the Debye-Hückel term:

$$
\begin{gathered}
\mathrm{D}=0.509 \mathrm{I}_{\mathrm{m}}{ }^{1 / 2} /\left(1+\mathrm{aBI}_{\mathrm{m}}{ }^{1 / 2}\right) \\
\Delta \varepsilon=\varepsilon_{\mathrm{Lp}}-\varepsilon_{\mathrm{H}}-\varepsilon_{\mathrm{Lq}}=-0.21^{18}
\end{gathered}
$$

with $\mathrm{Z}$ being the charge on the designated species, $\varepsilon$ is interaction parameter for each cation-anion pair and $\mathrm{aB}=$ 1.5 as suggested by Scatchard ${ }^{19}$.

Similar to above approach, the equilibrium constant $\mathrm{K}_{1}$ $\left(\mathrm{H}^{+}+\mathrm{H}_{2} \mathrm{PO}_{4}^{-}=\mathrm{H}_{3} \mathrm{PO}_{4}\right)$ values at the different temperatures were obtained by using SIT. The dissociation constants, $\mathrm{pK}_{\mathrm{a} 1}\left(=-\log \mathrm{K}_{\mathrm{a} 1}=\log \mathrm{K}_{1}\right)$ and $\mathrm{pK}_{\mathrm{a} 2}\left(=-\log \mathrm{K}_{\mathrm{a} 2}=\log \mathrm{K}_{2}\right)$, of phosphoric acid at different temperatures and at fixed ion strength of $1.0 \mathrm{M}$ $\mathrm{NaClO}_{4}$ listed in Table 1.

\section{Synergistic extraction}

The distribution experiments were conducted following the procedure described in the literature ${ }^{9-11}$. For each extraction experiment, $1.5 \mathrm{ml}$ of $1.0 \mathrm{M} \mathrm{NaClO}_{4}$ aqueous solution that contained desired amounts of $\mathrm{Na}_{2} \mathrm{HPO}_{4}$ at appropriate $\mathrm{pH}$ was mixed with an equal volume of $0.027 \mathrm{M}$ TTA with $0.0028 \mathrm{M}$ TOPO in toluene in a borosilicate glass vial. After addition of $10 \mu \mathrm{L}$ ${ }^{237} \mathrm{~Np}(\mathrm{~V})$ tracer, the vials were inserted into the temperature-controlled reaction block and shaken for two hours at the desired temperature. Kinetic studies confirmed that the extraction equilibrium was achieved in less than one hour. The vials were centrifuged at the same temperature as the reaction block on the shaker and aliquots of $0.5 \mathrm{ml}$ were taken from each phase to measure the $\alpha$-activity by LSC using OPTI Fluor as the scintillation cocktail. The remaining aqueous phase was used for $\mathrm{pH}$ measurement at the same temperature as the reaction block on the shaker.

\section{RESULTS AND DISCUSSION}

\section{$\mathrm{Np}(\mathrm{V})-\mathrm{HPO}_{4}{ }^{2-}$ complexes}

A series of experiments with constant $\mathrm{pcH}$ were conducted at an ionic strength of $1.0 \mathrm{M} \mathrm{NaClO}_{4}$. Distribution ratios (D) of $\mathrm{Np}(\mathrm{V})$ in the organic and aqueous phases were found to decrease with the increase in the concentration of $\mathrm{Na}_{2} \mathrm{HPO}_{4}$. A complete set of the extraction data at different temperatures are listed in Tables 2-4. The decrease in $\mathrm{D}$ can be attributed to the increase in concentration of $\mathrm{Np}(\mathrm{V})-\mathrm{HPO}_{4}{ }^{2-}$ complexes in the aqueous phase that are not extracted by TOPO+TTA. Stability constants of the 1:1 and 1:2 Np(V)- $\mathrm{HPO}_{4}{ }^{2-}$ complexes, dominant in the aqueous phase under the experimental conditions, were calculated from the effect of $\left[\mathrm{HPO}_{4}{ }^{2-}\right]$ on the distribution ratio.

Experiments have been conducted at $25^{\circ} \mathrm{C}, 40^{\circ} \mathrm{C}$ and $55^{\circ} \mathrm{C}$. A representative plot of $\mathrm{D}_{0} / \mathrm{D}$ versus the free concentration of $\mathrm{HPO}_{4}{ }^{2-}$ at $40 \pm 1^{\circ} \mathrm{C}$ is shown in Figure 1, where the points are experimental data and the solid line represents the fit for the formation of 1:1 and 1:2 complexes. From these data, the stability constants of $\mathrm{Np}(\mathrm{V})$ complexes with $\mathrm{HPO}_{4}{ }^{2-}$ at $25-55^{\circ} \mathrm{C}$ are calculated.

Literature data indicate that the hydrolysis of $\mathrm{Np}(\mathrm{V})$ is insignificant when $\mathrm{pcH}<8$ in the temperature range of $10-85^{\circ} \mathrm{C}^{20}$. Since the experiments in this study were 
conducted at $\mathrm{pcH} \sim 7.4$, the hydrolysis reactions of $\mathrm{Np}(\mathrm{V})$ are not included in the calculation.

The apparent stability constants obtained from this work are listed in Table 5 along with some literature data for comparison. The values at $25^{\circ} \mathrm{C}$ from this work (log $\left.\beta_{101}=2.32, \log \beta_{102}=3.78\right)$ are consistent with that in the literature data (see Table 5). The values at $40^{\circ} \mathrm{C}$ and $55^{\circ}$ $\mathrm{C}$ from this work are the first experimental values to be reported. The results show that the stability constant of 1:1 complex between $\mathrm{Np}(\mathrm{V})$ and $\mathrm{HPO}_{4}{ }^{2-}$ is decreased at higher temperatures. The tendency of the changing of stability constants with temperatures is similar to the literature data obtained from the temperatures from $10^{\circ} \mathrm{C}$ to $35^{\circ} \mathrm{C}^{6}$ (see Table 5). No stability constants of the $1: 2$ $\mathrm{Np}(\mathrm{V})-\mathrm{HPO}_{4}{ }^{2-}$ complex at elevated temperatures are available in the literature. The data obtained from this study indicate that the stability constants of $1: 2 \mathrm{~Np}(\mathrm{~V})$ $\mathrm{HPO}_{4}{ }^{2-}$ complex, are increased at higher temperatures (see Table 5).

As above mentioned, in the system of $\mathrm{Np}(\mathrm{V})$ phosphate complexes, there is possibility of the formation of different species of complexes including the complex reactions of $\mathrm{Np}(\mathrm{V})$ with $\mathrm{H}_{2} \mathrm{PO}_{4}^{-}$anions under experimental conditions used in this study. Therefore, during the calculation of stability constants of $\mathrm{Np}(\mathrm{V})$ with $\mathrm{HPO}_{4}{ }^{2-}$ complexes involved the stability constants of $\mathrm{Np}(\mathrm{V})$ with $\mathrm{H}_{2} \mathrm{PO}_{4}^{-}$complexes at different temperatures obtained from our previous data ${ }^{21}$ (see table 5). The following equation (13), derived from eq. (6) with the second dissociation constant, was used for corrected the stability constants:

$$
\beta_{\mathrm{q}}=\boldsymbol{\beta}_{\mathbf{q}}-\beta_{\mathrm{p}}\left[\mathrm{H}^{+}\right] / \mathrm{K}_{\mathrm{a} 2}
$$

where $\beta_{\mathrm{q}}$ is corrected stability constant, $\boldsymbol{\beta}_{\mathbf{q}}$ is fit data based on the experimental data in this study. The results show that both values of $\boldsymbol{\beta}_{\mathbf{q}}$ and $\beta_{q}$ are not significant different under the experimental conditions of this study.

\section{Effect of temperature on stability constants}

The effect of temperature on the stability constants of the $\mathrm{Np}(\mathrm{V})-\mathrm{HPO}_{4}{ }^{2-}$ complexes was evaluated at the range of temperature from $25^{\circ}$ to $55^{\circ} \mathrm{C}$. By using the Van't Hoff equation, we automatically assume that the enthalpy of complexation remains constant and an "average" enthalpy of complexation for this temperature range can be calculated. From the determined stability constants listed in the Table 5 , the corresponding values of $\Delta \mathrm{G}^{0^{\prime}}, \Delta \mathrm{H}^{\mathrm{o}^{\prime}}$, and $\Delta \mathrm{S}^{0^{\prime}}$ were calculated according to equation (14) and (15):

$$
\Delta \mathrm{G}^{\mathrm{o}^{\prime}}=-\mathrm{RT} \ln \beta
$$

$$
\operatorname{\rho ln} \beta / \partial(1 / T)=-\Delta \mathrm{H}^{\mathrm{o}^{\prime}} / \mathrm{R} ; \quad \Delta \mathrm{S}^{\mathrm{o}^{\prime}}=\left(\Delta \mathrm{H}^{\mathrm{o}^{\prime}}-\Delta \mathrm{G}^{\mathrm{o}^{\prime}}\right) / \mathrm{T}
$$

The calculated thermodynamic parameters are listed in Table 6. The results indicate that for the complex formation of $\mathrm{NpO}_{2}\left(\mathrm{HPO}_{4}\right)^{-}$the values of $\Delta \mathrm{H}^{\mathrm{o}^{\prime}}$ and $\Delta \mathrm{S}^{\mathrm{o}}$ are negative enthalpy which reflects no dehydration energy required to form complexes and supports the interpretation out sphere binding for the $\mathrm{Np}(\mathrm{V})$ complexes with $\mathrm{HPO}_{4}{ }^{2-22-24}$. While the enthalpy for the complex formation of $\mathrm{NpO}_{2}\left(\mathrm{HPO}_{4}\right)_{2}{ }^{3-}$ is positive and relatively large indicating the complex reactions are entropy-driven. The positive enthalpy reflects the dehydration energy required for forming complexes and supports the interpretation of inner sphere binding for the $\mathrm{Np}(\mathrm{V})$ complexes with $\mathrm{HPO}_{4}{ }^{2-22-24}$. These parameters should be helpful in predicting of the effect of temperature on the complexation of $\mathrm{Np}(\mathrm{V})$ with phosphate at elevated temperatures.

\section{CONCLUSIONS}

Stability constants of the $\mathrm{Np}(\mathrm{V})$ with $\mathrm{HPO}_{4}{ }^{2-}$ complexes were measured in aqueous solutions with $1.0 \mathrm{M} \mathrm{NaClO}_{4}$ as the background electrolyte at $\mathrm{pcH} \sim 7.4$ and at various temperatures (from 25 to $55^{\circ} \mathrm{C}$ ) by using synergistic extraction technique. Under the experimental conditions of this study, the 1:1 and 1:2 complexes $\left(\mathrm{NpO}_{2} \mathrm{HPO}_{4}{ }^{-}\right.$and $\left.\mathrm{NpO}_{2}\left(\mathrm{HPO}_{4}\right)_{2}{ }^{3-}\right)$ were found to be the dominant species. The stability constants of $1: 1 \mathrm{~Np}(\mathrm{~V})-$ $\mathrm{HPO}_{4}{ }^{2-}$ complexes are decreased with increasing temperature, consistent with a negative enthalpy of complexes and the out sphere complexes. While the stability constants of $1: 2 \mathrm{~Np}(\mathrm{~V})-\mathrm{HPO}_{4}{ }^{2-}$ complexes are increased with increasing temperature that are consistent with a positive enthalpy and the inner sphere complexes. These results have demonstrated that the temperature has a significant effect on the complexation of $\mathrm{Np}(\mathrm{V})$ with $\mathrm{HPO}^{2-}$ and it is important to conduct studies to evaluate the temperature effect to help predict the migration of neptunium in the high-level waste and in the proposed Yucca Mountain repository where temperature could be higher than the ambient temperature.

\section{ACKNOWLEDGEMENTS}

This work was supported by the Office of Civilian Radioactive Waste Management (OCRWM), U.S. Department of Energy at Pacific Northwest National Laboratory under Contract DE-AC06-76RLO 1830 and at Lawrence Berkeley National Laboratory under Contract DE-AC02-05CH11231. 


\section{REFERENCES}

1. Yucca Mountain Science and Engineering Report Rev. I, DOE/RW- 0539-1, Office of Civilian Radioactive Waste Management: North Las Vegas, NV (2002).

2. T. J. WOLERY and C. F. JOVE-COLON, "Qualification of Thermodynamic Data for Geochemical Modeling of Mineral-Water Interactions in Dilute Systems", ANL-WIS-GS000003 REV 00 ( November 2004).

3. J. FUGER, H. NITSCHE, P. POTTER, M. H. RAND, J. RYDBERG, K. SPAHIU, J. C. SULLIVAN, W. J. ULLMAN, P. VITORGE, H. WANNER, Chemical Thermodynamics of Neptunium and Plutonium. Edited by OECD Nuclear Energy Agency, Data Bank, Chemical Thermodynamics 4, Elsevier, New York (2001).

4. A. MORGENSTERN, J. I. Kim, Radiochim. Acta, 72, 73, (1996).

5. A. I. MOSKVIN, V. F. PERETRUKHIN, Sov. Radiochem., 6, 198 (1964).

6. T. F. REES, S. R. DANIEL, Polyhedron, 3, 667 (1984).

7. Y. INOUE, O. TOCHIYAMA, Bull. Chem. Soc. Jpn. 58, 2228 (1985).

8. A. I. MOSKVIN, A. N. POZNYAKOV, J. Inorg. Chem., 24, 1357 (1979).

9. G. R. CHOPPIN, H. N. ERTEN, Y. XIA, Radiochim. Acta, 74, 123 (1996).
10. Y XIA, L. RAO, D. RAI, A. R. FELMY, Radiochim. Acta, 86, 33 (1999).

11. Y. XIA, J. I. FRIESE, D. A. MOORE, L. RAO, J. Radioanal. Nucl. Chem., 268, 3, 445-451 (2006).

12. L. RAO, G. R. CHOPPIN, Inorg. Chem., 23, 23512354 (1984).

13. H. M. IRVING, M. G. MILES, L. D. PETTIT, Anal. Chem. Acta, 38, 475, (1967).

14. A.E. MARTELL, R. M. SMITH, Critical Selected Stability Constants of Metal Complexes Database. NIST Standard Reference Database 46 Version 7.0 (2003).

15. J. I. PARTANEN, A. K. COVINGTON, J. Chem. Eng. Data 50, 2065-2073 (2005).

16. L.P. NIMS, J. Am. Chem. Soc., 56, 110112 (1934).

17. I. GRENTHE, J. FUGER, R.J. LEMIRE, A.B. MULLER, C.N. CREGV, H. WANNER, NEA-TDB, OECD. France (1991).

18. L. RAO, Private Communication, 2008.

19. G. SCATCHARD, Chem. Rev. 19, 309 (1936).

20. L. RAO, T. G. SRINIVASAN, A. GAMOV, YU, P. ZANONATO, P. DI BERNARDO, A. BISMONDO, Geochim. Cosmochim. Acta, 68, 4821 (2004).

21. Y. XIA, J. I. FRIESE, D.A. MOORE, L. RAO, Proc. Of 2006 International High-Level Radioactive Waste Management Conference, Las Vegas, Nevada, USA (2006).

22. R.G. PEARSON, J. Chem. Educ., 45, 581 (1968).

23. R.G. PEARSON, J. Chem. Educ., 45, 643 (1968).

24. S. AHRLAND, Coord. Chem. Rev.8, 21 (1972). 
Table 1. The dissociation constants of phosphoric acid at the different temperatures and fixed ionic strength of $1.0 \mathrm{M} \mathrm{NaClO}_{4}$

\begin{tabular}{ccccc}
\hline Temperature $\left({ }^{\circ} \mathrm{C}\right)$ & Ionic Strength & $\mathrm{pK}_{\mathrm{a} 1}$ & $\mathrm{pK}_{\mathrm{a} 2}$ & Reference \\
\hline 25 & $1.0 \mathrm{M} \mathrm{NaClO} 4$ & 1.780 & 6.595 & 18 \\
40 & $1.0 \mathrm{M} \mathrm{NaClO} 4$ & 1.841 & 6.558 & 18 \\
55 & $1.0 \mathrm{M} \mathrm{NaClO} 4$ & 1.926 & 6.539 & 18 \\
\hline
\end{tabular}

The $\mathrm{pK}_{\mathrm{a} 1}\left(=-\log \mathrm{K}_{\mathrm{a} 1}\right)$ at different temperatures and $\mathrm{I}=1.0 \mathrm{M} \mathrm{NaClO}_{4}$ obtained from the literature data $\mathrm{pK}_{\mathrm{al}}{ }^{16}=2.124\left(25^{\mathrm{c}} \mathrm{O}, \mathrm{I}=0\right), 2.198\left(40^{\circ} \mathrm{C}, \mathrm{I}=0\right)$ and $2.294\left(55^{\circ} \mathrm{C}, \mathrm{I}=0\right)$ by using SIT approach.

The $\mathrm{pK}_{\mathrm{a} 2}\left(=-\log \mathrm{K}_{\mathrm{a} 2}\right)$ at different temperatures and $\mathrm{I}=1.0 \mathrm{M} \mathrm{NaClO}_{4}$ obtained from the literature data $\mathrm{pK}_{\mathrm{a} 2}{ }^{15}$ by using SIT approach.

Table2. Solvent extraction data for the synergistic extraction system of $\mathrm{Np}(\mathrm{V})-\mathrm{HPO}_{4}^{2-}-1.0 \mathrm{M} \mathrm{NaClO}_{4}-0.027 \mathrm{M}$ TTA + $0.028 \mathrm{M}$ TOPO in toluene at $25 \pm 1^{\circ} \mathrm{C}$

\begin{tabular}{lllll}
\hline $\mathrm{pcH}$ & {$\left[\mathrm{HPO}_{4}{ }^{2-}\right]_{\mathrm{T}}, \mathrm{M}$} & $\begin{array}{l}\text { Activity, cpm } \\
\text { Org. Phase }\end{array}$ & $\begin{array}{l}\text { Activity, cpm } \\
\text { Aq. Phase }\end{array}$ & $\mathrm{D}$ \\
\hline 7.57 & 0 & 6617 & 519 & 12.80 \\
7.55 & $1.00 \mathrm{e}-04$ & 6542 & 536 & 12.25 \\
7.52 & $3.00 \mathrm{e}-04$ & 6473 & 549 & 11.84 \\
7.56 & $6.00 \mathrm{e}-04$ & 6381 & 559 & 11.45 \\
7.56 & $9.00 \mathrm{e}-04$ & 6380 & 602 & 10.63 \\
7.60 & $1.80 \mathrm{e}-03$ & 6379 & 682 & 9.38 \\
7.56 & $2.40 \mathrm{e}-03$ & 6352 & 742 & 7.59 \\
7.56 & $3.00 \mathrm{e}-03$ & 6193 & 787 & 7.88 \\
\hline
\end{tabular}

$\mathrm{pcH}=-\log \left[\mathrm{H}^{+}\right]$. The activity of background: $2.0 \mathrm{cpm}$. 
Table 3. Solvent extraction data for the synergistic extraction system of $\mathrm{Np}(\mathrm{V})-\mathrm{HPO}_{4}^{2-}-1.0 \mathrm{M} \mathrm{NaClO}_{4}-0.027 \mathrm{M}$ TTA + $0.028 \mathrm{M}$ TOPO in toluene at $40 \pm 1^{\circ} \mathrm{C}$

\begin{tabular}{lllll}
\hline $\mathrm{pcH}$ & {$\left[\mathrm{H}_{2} \mathrm{PO}_{4}{ }^{2-}\right]_{\mathrm{T}}, \mathrm{M}$} & $\begin{array}{l}\text { Activity, cpm } \\
\text { Org. Phase }\end{array}$ & $\begin{array}{l}\text { Activity, cpm } \\
\text { Aq. Phase }\end{array}$ & $\mathrm{D}$ \\
\hline 7.45 & 0 & 8790 & 564 & 15.59 \\
7.44 & $3.00 \mathrm{e}-04$ & 8777 & 574 & 15.31 \\
7.40 & $6.00 \mathrm{e}-04$ & 8760 & 586 & 14.97 \\
7.45 & $1.30 \mathrm{e}-03$ & 8637 & 644 & 13.42 \\
7.42 & $1.70 \mathrm{e}-03$ & 8406 & 652 & 12.91 \\
7.47 & $1.90 \mathrm{e}-03$ & 8398 & 660 & 12.74 \\
7.41 & $2.10 \mathrm{e}-03$ & 8344 & 669 & 12.48 \\
7.42 & $2.50 \mathrm{e}-03$ & 8331 & 705 & 11.82 \\
\hline
\end{tabular}

$\left.\mathrm{pcH}=-\log \left[\mathrm{H}^{+}\right], \mathrm{H}_{2} \mathrm{PO}_{4}{ }^{2-}\right]_{\mathrm{T}}$-total concentration of $\mathrm{Na}_{2} \mathrm{HPO}_{4}$, the activity of background: $0.5 \mathrm{cpm}$.

Table 4. Solvent extraction data for the synergistic extraction system of $\mathrm{Np}(\mathrm{V})-\mathrm{HPO}_{4}^{2-}-1.0 \mathrm{M} \mathrm{NaClO}_{4}-0.027 \mathrm{M} \mathrm{TTA}+$ $0.028 \mathrm{M}$ TOPO in toluene at $55 \pm 1^{\circ} \mathrm{C}$

\begin{tabular}{lllll}
\hline $\mathrm{pcH}$ & {$\left[\mathrm{H}_{2} \mathrm{PO}_{4}{ }^{2-}\right]_{\mathrm{T}}, \mathrm{M}$} & $\begin{array}{l}\text { Activity, cpm } \\
\text { Org. Phase }\end{array}$ & $\begin{array}{l}\text { Activity, cpm } \\
\text { Aq. Phase }\end{array}$ & $\mathrm{D}$ \\
\hline 7.35 & 0 & 3423 & 246 & 13.99 \\
7.35 & $6.50 \mathrm{e}-04$ & 3398 & 270 & 12.63 \\
7.35 & $1.00 \mathrm{e}-03$ & 3397 & 272 & 12.57 \\
7.35 & $1.40 \mathrm{e}-03$ & 3391 & 277 & 12.29 \\
7.36 & $1.80 \mathrm{e}-03$ & 3378 & 290 & 11.69 \\
7.36 & $2.20 \mathrm{e}-03$ & 3366 & 303 & 11.17 \\
7.33 & $2.60 \mathrm{e}-03$ & 3347 & 322 & 10.45 \\
7.36 & $3.10 \mathrm{e}-03$ & 3339 & 329 & \\
\hline
\end{tabular}

$\left.\mathrm{pcH}=-\log \left[\mathrm{H}^{+}\right], \mathrm{H}_{2} \mathrm{PO}_{4}{ }^{2-}\right]_{\mathrm{T}}-$ total concentration of $\mathrm{Na}_{2} \mathrm{HPO}_{4}$, the activity of background: $1.3 \mathrm{cpm}$ 


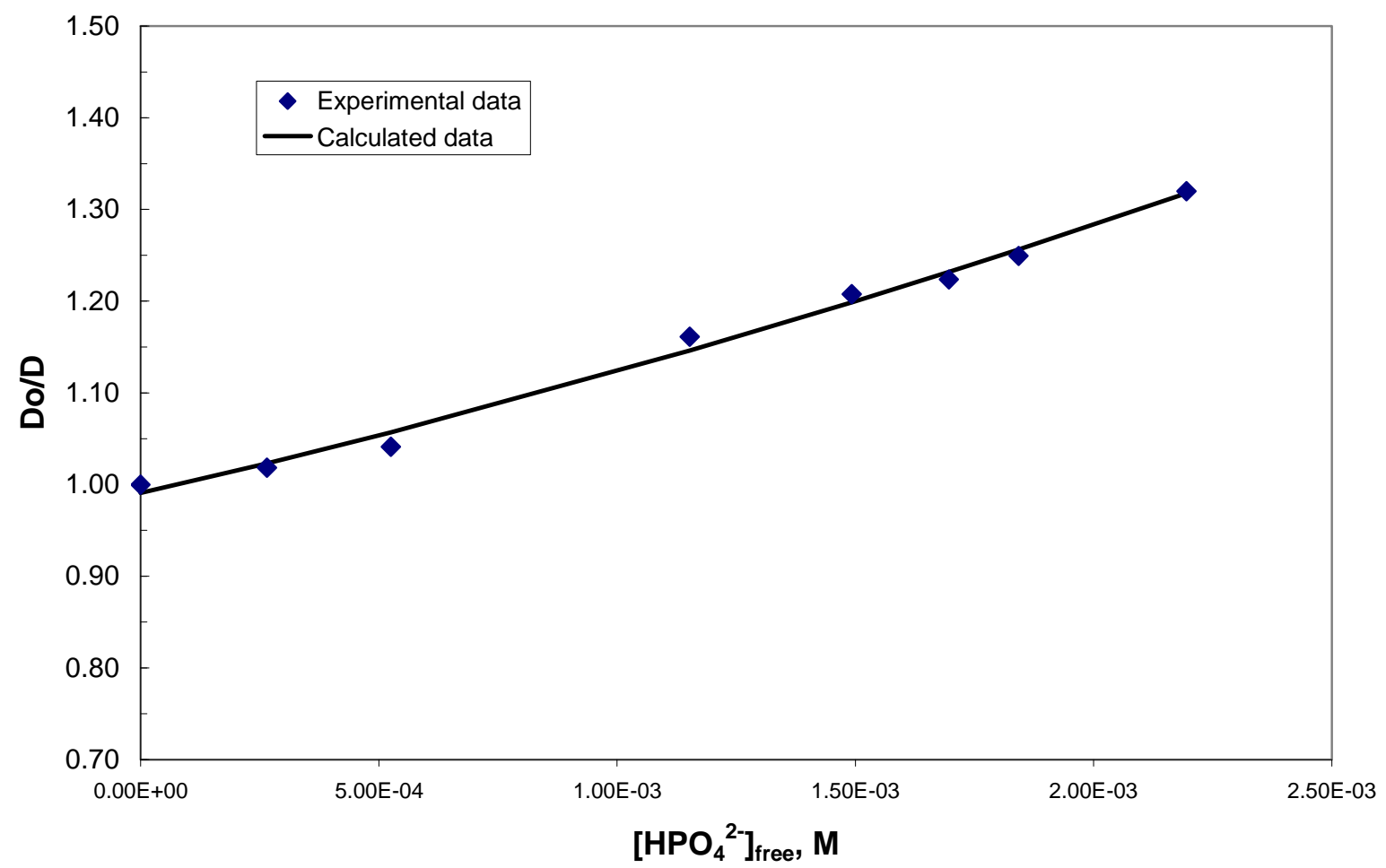

Figure 1. Plot of Do/D vs. concentrations of phosphate in the synergistic extraction system of $\mathrm{Np}(\mathrm{V})-1.0 \mathrm{M}$ NaClO4-0.027 M TTA+0.028 M TOPO in toluene at $40^{\circ} \mathrm{C}$ 
Table 5. Apparent stability constants for $\mathrm{Np}(\mathrm{V})$ phosphate complexes including literature data

\begin{tabular}{|c|c|c|c|c|c|}
\hline Method & Ionic medium & $\begin{array}{c}\text { Temperature, } \\
\left({ }^{\circ} \mathrm{C}\right)\end{array}$ & $\log \beta_{101}$ & $\log \beta_{102}$ & Reference \\
\hline \multicolumn{6}{|c|}{$\mathrm{NpO}_{2}^{+}+\mathrm{H}_{2} \mathrm{PO}_{4}^{-}=\mathrm{NpO}_{2} \mathrm{H}_{2} \mathrm{PO}_{4}(\mathrm{aq})$} \\
\hline $\begin{array}{l}\text { dis } \\
\text { dis } \\
\text { dis } \\
\text { dis }\end{array}$ & $\begin{array}{l}1.0 \mathrm{M} \mathrm{NaClO}_{4} \\
1.0 \mathrm{M} \mathrm{NaClO}_{4} \\
1.0 \mathrm{M} \mathrm{NaClO}_{4} \\
1.0 \mathrm{M} \mathrm{NaClO}_{4}\end{array}$ & $\begin{array}{l}25 \\
25 \\
40 \\
55\end{array}$ & $\begin{array}{l}1.04 \pm 0.18 \\
1.18 \pm 0.10 \\
1.39 \pm 0.06 \\
1.63 \pm 0.03\end{array}$ & & $\begin{array}{c}7 \\
21 \\
21 \\
21\end{array}$ \\
\hline \multicolumn{6}{|c|}{$\mathrm{NpO}_{2}^{+}+\mathrm{HPO}_{4}{ }^{2-}=\mathrm{NpO}_{2} \mathrm{HPO}_{4}^{-}$} \\
\hline $\begin{array}{l}\text { cix } \\
\text { cppt } \\
\text { cix } \\
\text { cix } \\
\text { cix } \\
\text { dis } \\
\text { sp } \\
\text { dis } \\
\text { dis } \\
\text { dis }\end{array}$ & $\begin{array}{l}0.2 \mathrm{M} \mathrm{NH}_{4} \mathrm{ClO}_{4} \\
1 \mathrm{M} \mathrm{NH}_{4} \mathrm{Cl} \\
0.1 \mathrm{M} \mathrm{NaClO}_{4} \\
0.1 \mathrm{M} \mathrm{NaClO}_{4} \\
0.1 \mathrm{M} \mathrm{NaClO}_{4} \\
1.0 \mathrm{M} \mathrm{NaClO}_{4} \\
0.1 \mathrm{M} \mathrm{NaClO}_{4} \\
1.0 \mathrm{M} \mathrm{NaClO}_{4} \\
1.0 \mathrm{M} \mathrm{NaClO}_{4} \\
1.0 \mathrm{M} \mathrm{NaClO}_{4}\end{array}$ & $\begin{array}{l}20 \\
20 \\
10 \\
25 \\
35 \\
25 \\
25 \\
25 \\
40 \\
55\end{array}$ & $\begin{array}{l}2.85 \pm 0.15 \\
2.9 \pm 0.1 \\
3.11 \pm 0.19 \\
2.36 \pm 0.42 \\
2.06 \pm 0.39 \\
2.11 \pm 0.09 \\
2.54 \pm 0.02 \\
2.32 \pm 0.04 \\
2.08 \pm 0.06 \\
1.99 \pm 0.13\end{array}$ & & $\begin{array}{c}5 \\
8 \\
6 \\
6 \\
6 \\
7 \\
4 \\
\text { This work } \\
\text { This work } \\
\text { This work }\end{array}$ \\
\hline \multicolumn{6}{|c|}{$\mathrm{NpO}_{2}^{+}+2 \mathrm{HPO}_{4}^{2-}=\mathrm{NpO}_{2}\left(\mathrm{HPO}_{4}\right)_{2}^{3-}$} \\
\hline $\begin{array}{l}\text { dis } \\
\text { dis } \\
\text { dis } \\
\text { dis }\end{array}$ & $\begin{array}{l}1.0 \mathrm{M} \mathrm{NaClO}_{4} \\
1.0 \mathrm{M} \mathrm{NaClO}_{4} \\
1.0 \mathrm{M} \mathrm{NaClO}_{4} \\
1.0 \mathrm{M} \mathrm{NaClO}_{4}\end{array}$ & $\begin{array}{l}25 \\
25 \\
40 \\
55\end{array}$ & & $\begin{array}{l}3.43 \pm 0.16 \\
3.78 \pm 0.35 \\
4.14 \pm 0.25 \\
4.22 \pm 0.24\end{array}$ & $\begin{array}{c}7 \\
\text { This work } \\
\text { This work } \\
\text { This work }\end{array}$ \\
\hline
\end{tabular}

Dis: solvent extraction; cix: ion exchange; cppt: co-precipitation method ; sp: spectrophotometric method. 
Table 6. Stability constant and thermodynamic values for $1: 1$ and $1: 2$ complexes of $\mathrm{Np}(\mathrm{V})$ with $\mathrm{HPO}_{4}{ }^{2-}$

\begin{tabular}{ccccccc}
\hline $\begin{array}{c}\text { Temperature } \\
{ }^{\circ} \mathrm{C}\end{array}$ & Ionic strength & $\log \beta_{101}$ & $\log \beta_{102}$ & $\begin{array}{c}\Delta \mathrm{G}^{\mathrm{o}^{\prime}} \\
\mathrm{kJ} / \mathrm{mol}\end{array}$ & $\begin{array}{c}\Delta \mathrm{S}^{\mathrm{o}^{\prime}} \\
\mathrm{J} / \mathrm{K} \text { mol }\end{array}$ & $\begin{array}{c}\Delta \mathrm{H}^{\mathrm{o}^{\prime}} \\
\mathrm{kJ} / \mathrm{mol}\end{array}$ \\
\hline
\end{tabular}

For the complex formation of $\mathrm{NpO}_{2}{ }^{+}+\mathrm{HPO}_{4}{ }^{2-}=\mathrm{NpO}_{2} \mathrm{HPO}_{4}{ }^{-}$

$\begin{array}{lllllll}25 & 1.0 & 2.32 \pm 0.04 & -13.25 & -25.14 & -20.74 & \text { this work } \\ 40 & 1.0 & 2.08 \pm 0.06 & -12.47 & -26.40 & -20.74 & \text { this work } \\ 55 & 1.0 & 1.99 \pm 0.13 & -12.50 & -25.10 & -20.74 & \text { this work }\end{array}$

For the complex formation of $\mathrm{NpO}_{2}{ }^{+}+2 \mathrm{HPO}_{4}{ }^{2-}=\mathrm{NpO}_{2} \mathrm{HPO}_{4}{ }^{3-}$

\begin{tabular}{lllllll}
25 & 1.0 & $3.78 \pm 0.35$ & -21.56 & 165.41 & 27.73 & this work \\
40 & 1.0 & $4.14 \pm 0.25$ & -24.63 & 167.85 & 27.73 & this work \\
55 & 1.0 & $4.22 \pm 0.24$ & -26.52 & 165.33 & 27.73 & this work \\
\hline
\end{tabular}

